stitutes have been used satisfactorily; the necessity for giving complete vitamin supplements is stressed.

We thank the consulting physicians at the Hospital for Sick Children for permission to study patients under their care. It is a great pleasure to acknowledge the close collaboration of $\mathrm{Mr}$. J. V. Hyde, of Trufood Ltd., throughout this work. We are indebted to Mr. R. Ersser for technical assistance. We gratefully acknowledge financial support from the Joint Research Board of the Hospital for Sick Children and Institute of Child Health.

\section{REFERENCES}

Anderson, C. M., Kerry, K. R., and Townley, R. R. W. (1965). Arch. Dis. Childh., 40, 1.

Arthur, A. B. Clayton, B. E., Cottom, D. G., Seakins, J. W. T., and Platt, J. W. (1966). Lancet, 1, 172.
Bowie, M. D., Brinkman, G. L., and Hansen, J. D. L. (1965). F. Pediat., 66, 1083 .

Burke, V., Kerry, K. R., and Anderson, C. M. (1965). Aust. paediat. 7., $1,147$.

Careddu, P., Giovannini, M., and Cevini, G. (1963). Helv. paediat. Acta, 18, 97 .

Cozzetto, F. J. (1963). Pediatrics, 32, 228.

Durand, P. (1964). In Disorders Due to Intestinal Defective Carbokydrate Digestion and Absorption, edited by P. Durand. Pensiero Scientifico, Rome.

Finkelstein, H., and Meyer, L. F. (1911). Münch. med. Wschr., 58, 340.

Howland, J. (1921). Trans. Amer. pediat. Soc., 33, 11.

Lifshitz, F., Klotz, A. P., and Holman, G. H. (1965). Amer. 7. dig. Dis., io, 47.

Mann, T. P., Wilson, K. M., and Clayton, B. E. (1965). Arch. Dis. Childh., 40, 364.

Plotkin, G. R., and Isselbacher, K. J. (1964). New Engl. F. Med., 271, 1033.

Santini, R., Aviles, J., and Sheehy, T. W. (1960). Amer. F. dig. Dis., 5, Westall, R. G. (1963). Arch. Dis. Childh., 38, 485.

\title{
Ehlers-Danlos Syndrome: Associated with Prematurity and Premature Rupture of Foetal Membranes; Possible Increase in Incidence
}

\author{
A. P. BARABAS, ${ }^{*}$ M.B., F.R.C.S.
}

Brit. med. F., 1966, 2, 682-684

The Ehlers-Danlos syndrome is an inherited disorder of the connective tissue. It belongs to the same group of disorders as the Marfan syndrome, osteogenesis imperfecta, and pseudooxanthoma elasticum (McKusick, 1960). The main clinical features are: (1) fragility of the skin and of the dermal bloodvessels, (2) characteristic " papyraceous" scars, (3) hyperextensible skin, and (4) hypermobile joints. The basic defect is believed to lie in the organization of collagen into a stable collagen "wickerwork" (Jansen, 1955).

In this article evidence is presented that most babies with Ehlers-Danlos syndrome are born prematurely after premature rupture of foetal membranes. In all patients the fragility of foetal membranes (as shown by the degree of prematurity) is well correlated with the fragility of skin (as shown by the amount of skin-scarring). Finally, it is argued that in countries with gond antenatal and premature-infant care an increase in the number of surviving Ehlers-Danlos patients is likely.

These observations were made on a group of 39 affected individuals-the largest series of Ehlers-Danlos patients so far recorded. The syndrome is generally regarded as extremely rare, but this is due partly to a failure to recognize less obvious cases.

\section{Material and Diagnosis}

Twenty patients were personally examined, and in the remaining 19 detailed hospital records were available. The diagnosis of Ehlers-Danlos syndrome was made on clinical signs, since there are no specific laboratory, radiological, or histological findings. A biopsy of the skin was carried out in half of the patients: in every case microscopical appearances were compatible with the diagnosis of Ehlers-Danlos syndrome.

All patients reported here had a tendency to excessive bruising, laceration of the skin after minor trauma, and varying degrees of skin hyperextensibility and joint hypermobility. In every patient characteristic thin hyperpigmented scars, especi-

* Surgical Registrar, the Postgraduate Medical School of London and Hammersmith Hospital, London. ally over the knees, shins, and forehead, were found (Figs. 1 and 2).

Prematurity was defined as a birthweight of less than $5 \frac{1}{2} \mathrm{lb}$. (2,500 g.) (British Medical fournal, 1961). Rupture of the foetal membranes is defined as "premature" where this occurs before the onset of labour.

\section{Results}

Prematurity.-In 18 of the 39 patients studied details of the circumstances of birth were known ; 14 were born prematurely and in four the birth-weight exceeded $5 \frac{1}{2} \mathrm{lb}$. Premature babies were born between the 32nd and 35th weeks of pregnancy. They were premature, therefore, not only by their birth-weight but by dates as well. Three of the four nonpremature affected babies were born in the same family (Fig. 3, Cases 16, 17, and 18).

Premature Rupture of Foetal Membranes.-In 13 of the 14 premature births labour definitely started after rupture of foetal membranes. Such occurred also in two out of the four nonpremature births. The time of rupture was not recorded in the remaining three births. However, in no birth of an EhlersDanlos baby could premature rupture of the membranes definitely be excluded.

Correlation between Birth-weight and Clinical Picture.-The present series is too small for any definite statement to be made on this correlation. However, among all examined patients the one case (Case 4) with the lowest birth-weight, $3 \frac{1}{2} \mathrm{lb}$. (1,590 g.), had the most severe scarring and another patient (Case 8) with the highest birth-weight, $7 \frac{1}{2} \mathrm{lb}$. (3,400 g.), had the least scarring of the skin (Figs. 1 and 2). Also, in every patient between these two extremes the birth-weight and amount of scarring seemed to be well correlated.

Unaffected Members of Ehlers-Danlos Families.-In the one case where a mother with clinical signs of Ehlers-Danlos syndrome (Fig. 3, Case 9) gave birth to a normal child, and the circumstance of birth was known, the child was not premature and the foetal membranes ruptured in the second stage of 
labour. Normal siblings of premature babies with EhlersDanlos syndrome were never premature, and had no history of premature rupture of foetal membranes (with the exception of the normal twin brother of Case 11).

\section{Prematurity}

\section{Discussion}

Premature birth of babies with Ehlers-Danlos syndrome has been noted by many previous authors (Ronchese, 1936 ; Johnson and Falls, 1949 ; Mories, 1954), but there has never been an explanation for this nor has prematurity been generally recognized as part of the syndrome. Mories (1954) is the only author who estimated the frequency of prematurity in a group of patients ; among his 17 cases only $30 \%$ were born premature. He observed, however, that had it not been for one large family, in whom no premature birth occurred, the percentage would have been much higher-about $60 \%$. In the present series 14 out of 18 cases $(78 \%)$ were born prematurely (incidence of prematurity in England and Wales $8 \%$, British Medical

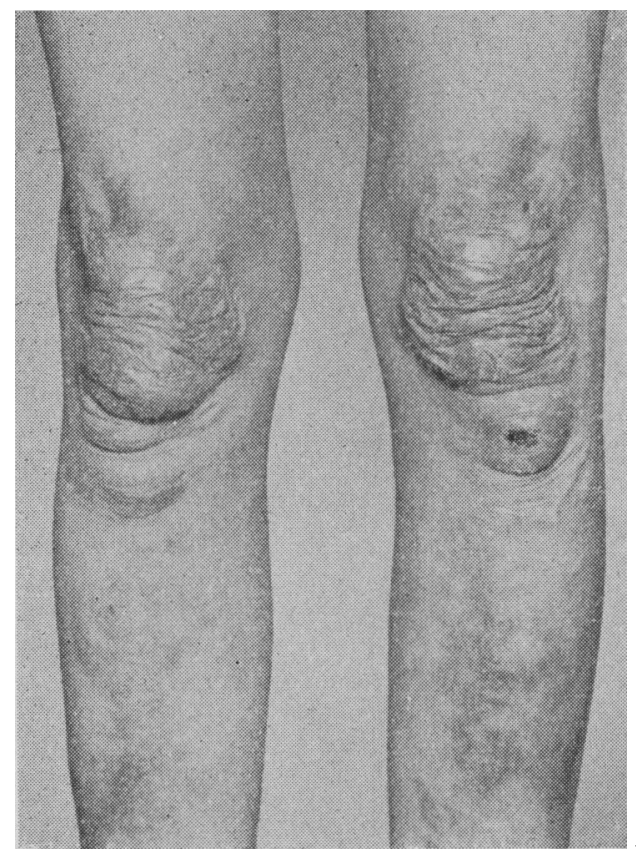

FIG. 1.-Severe scarring of the skin in patient (Case 4) with the lowest birth-weight ( $3 \frac{1}{2}$ lb. ; 1,590 g.) in this series.

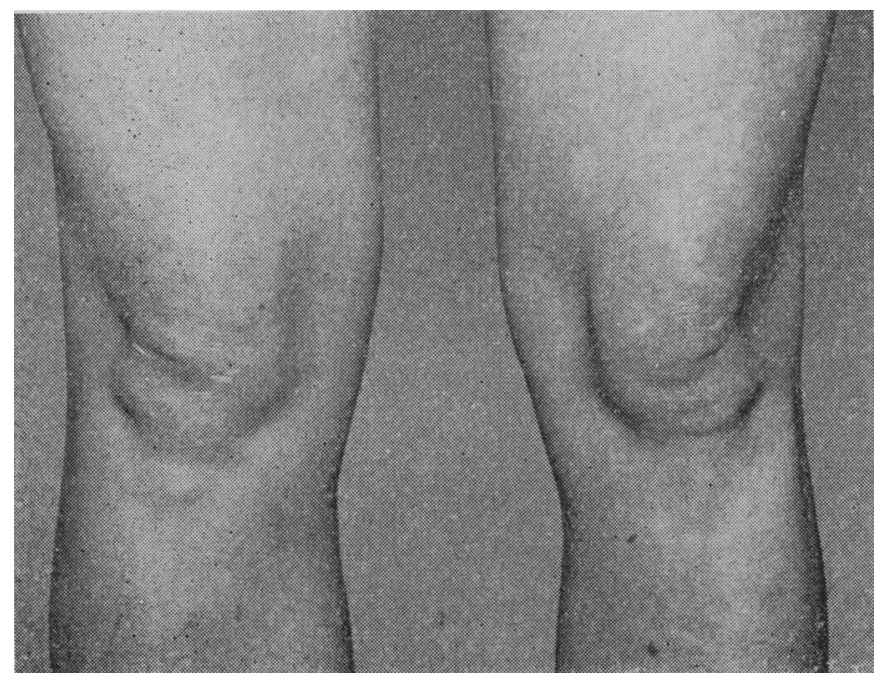

FIG. 2.-Minor scarring of the skin in patient (Case 8), with the highest birth-weight $\left(7 \frac{1}{2}\right.$ lb. ; 3,400 g.) in this series.
Fournal, 1961). One family with no prematurity accounted for three of the four non-premature births.

In the two families without prematurity from the Mories and the present series the first fore-parents with known EhlersDanlos syndrome were born in the first half of the nineteenth century. In most families with prematurity, on the other hand, Ehlers-Danlos syndrome first occurred in a grandparent, parent, or propand born well within the twentieth century. It would seem, therefore, that in the past only those who were not premature-born have survived and have reproduced successfully. Today's improved antenatal and premature-infant care may succeed in keeping alive those patients who showed prematurity as well.

\section{Cause of Prematurity}

In all Ehlers-Danlos babies in this series (where the circumstances of birth were known) rupture of foetal membranes preceded the onset of labour. The foetal membranes develop from the same fertilized ovum as the embryo, and their tensile strength depends mainly on a central collagenous layer; they do not rupture, as a rule, until the onset of uterine contractions in labour. Premature rupture of membranes is known to lead to the onset of labour and is a standard practice to induce labour.

The following hypothesis may therefore be formulated. In Ehlers-Danlos syndrome the fragility of the foetal tissues is shared by the foetal membranes. Towards the end of pregnancy, wisen further decrease in the strength of foetal mem-

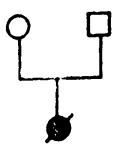

1

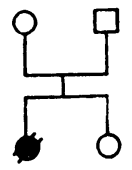

2

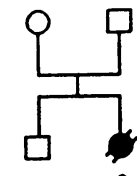

3

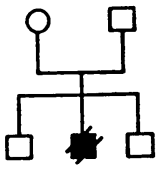

4

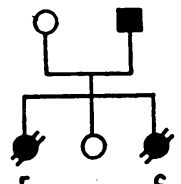

5
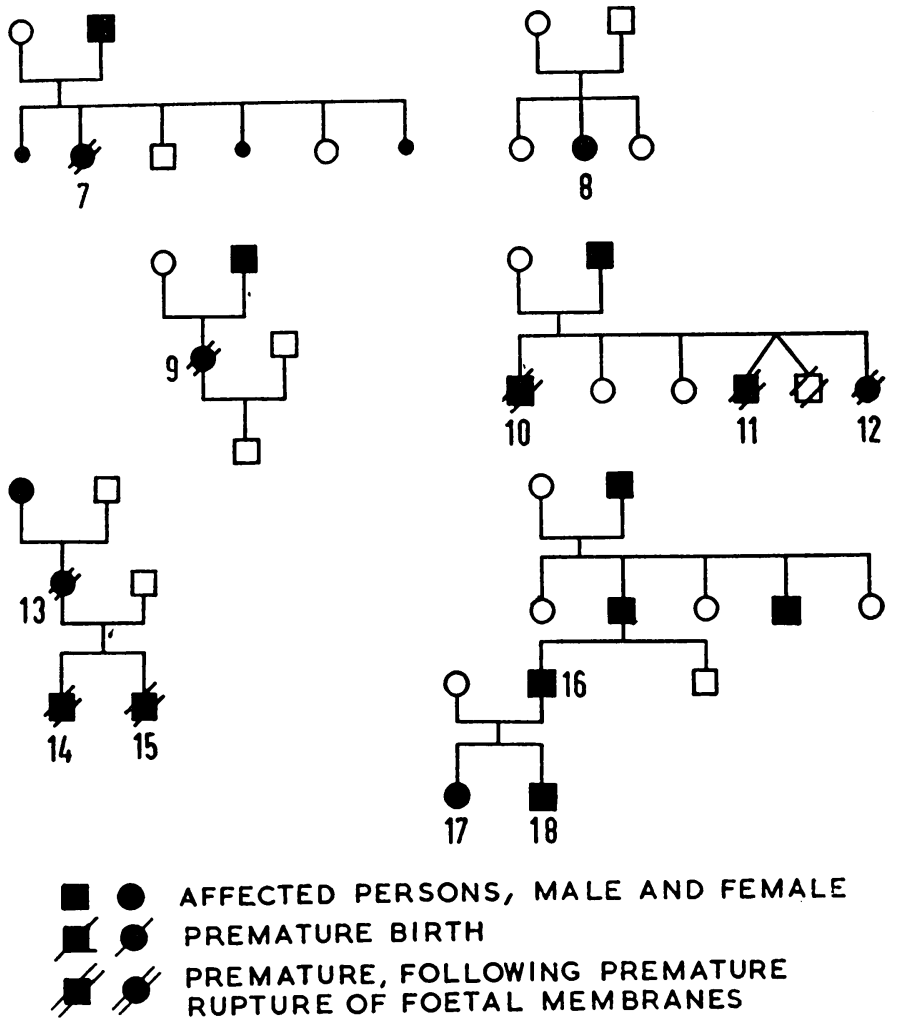

AFFECTED PERSONS, MALE AND FEMALE PREMATURE BIRTH PREMATURE, FOLLOWING PREMATURE RUPTURE OF FOETAL MEMBRANES STILLBIRTH

FIG. 3.-Family trees of 18 Ehlers-Danlos patients in whom the circumstance of birth was known. 
branes normally occurs (Harkness and Harkness, 1956), these defective foetal membranes break. The ensuing labour results in the premature birth of nearly all those babies affected by the syndrome.

\section{Is there an Increase in the Incidence of Ehlers-Danlos Syndrome?}

Most patients with Ehlers-Danlos syndrome have striking clinical signs, yet apparently these were not recognized before the end of the nineteenth century. At that time several single examples were presented at meetings of dermatological societies in various European countries (Morris, 1900 ; Ehlers, 1901 ; Danlos, 1908). Full clinical descriptions were published only in the 1930s, when most authors stressed the extreme rarity of the condition (Ronchese, 1936).

Nevertheless, more recently large series of patients have been collected with relative ease: 17 cases in Britain by Mories (1954), 14 families in the United States of America by McKusick (1960), and the present 39 cases, mainly found among patients attending two large teaching hospitals in England.

In the highly developed countries of Europe and in the U.S.A. individual cases are now reported only if they present some unusual features, such as an association of the syndrome with any of the following: Marfan syndrome (Goodman et al., 1965), multiple neurofibromatosis (Goodman et al., 1962), congenital heart disease (Bopp et al., 1965), arterial rupture (Mories, 1960 ; McFarland and Fi:ler, 1964), or arteriovenous fistulae (Lynch et al., 1965). Since these unusual features and serious complications are rarely observed among the patients of the large unselected series (Mories, 1954), it may be assumed that a great number of ordinary cases are seen but remain unreported.

In countries other than America, Scandinavia, and Western Europe, Ehlers-Danlos syndrome still seems to be a great rarity, as only recently have first descriptions of individual uncomplicated cases started to be published (Chakraborty et al., 1954).

\section{Summary}

Eighteen patients with Ehlers-Danlos syndrome were studied, and their circumstances of birth are reported in this paper.

Fourteen patients $(78 \%)$ were born prematurely, owing to premature rupture of the foetal membranes. Most-of the nonpremature births occurred in one large exceptional family.

It seems likely that there will be an increase in the number of patients surviving with Ehlers-Danlos syndrome in those countries which provide good antenatal and premature-infant care.

I am grateful to Professor A. M. Boyd, Dr. M. C. G. Israels, and Mr. D. Ll. Griffiths, of Manchester Royal Infirmary, Mr. V. J. Downie, of Barnet General Hospital, and Mr. G. E. Thomas, of the United Liverpool Hospital, for allowing me to study their cases. My thanks are also due to Mr. J. S. Calnan, of the Postgraduate Medical School, London, for his help in the preparation of this article ; to Miss Anne Dainton for secretarial help ; to the Medical Illustration Department, Manchester Royal Infirmary, for Figs. 1 and 2 ; and to Miss Ann Baker for Fig. 3.

\section{REFERENCES}

Brit. med. f., 1961, 1, 1225.

Bopp, P., Hatam, K., Bussat, P., Greder, G., and Duchosal, P. W.' (1965). Circulation, 32, 602 .

Chakraborty, A. N., Banerjee, A. K., and Ghosh, S. (1954). F. Indian med. Ass., 23, 344

Danlos, H. (1908). Bull. Soc. franç. Derm. Syph., 19, 70.

Ehlers, E. (1901). Derm. Z., 8, 173.

Goodman, R. M., Levitsky, J.' M., and Friedman, I. A. (1962). Amer. f. Med., 32, 976.

Wooley, C. F., Frazier, R. L., and Covault, L. (1965). New Engl. 7. Med., 273, 514 .

Harkness, M. L. R., and Harkness, R. D. (1956). F. Physiol. (Lond.), 132,482 .

Jansen, L. H. (1955). Dermatologica (Basel), 110, 108.

Jansen, L. H. (1955). Dermatologica (Basel), 110, 108. Syph. (Chic.), 60,82 .

Lynch, H. T., Larsen, A. L., Wilson, R., and Magnuson, C. L. (1965). f. Amer. med. Ass., 194, 1011.

McFarland, W., and Fuller, D. E. (1964). New Engl. F. Med., 271, 1309. McKusick, V. A. (1960). Heritable Disorders of Connective Tissue, 2nd ed. Mbsby, St. Louis.

Mories, A. (1954). M.D. Thesis, Edinburgh University.

Mories, A. (1960). Scot. med. F., 5, 269.

Morris, M. (1900). Brit. f. Derm., 12, 208.

Monchese, F. (1936). Amer. f. Dis. Child., 51, 1403.

\section{Medical Memoranda}

\section{Spinal Cysticercosis with Paraplegia}

\author{
Brit. med. F., 1966, 2, 684-585
}

Cysticerus cellulosae, the systemic form of infection with the larvae of the pork tapeworm, is an uncommon condition in man, as the larval stage generally develops in the pig. Occasionally, however, the cysticercosis stage of Taenia solium is found in man. The ova of $T$. solium after ingestion are carried to various parts of the body, where they develop into cysticerci. The common sites of localization are the nervous system, skeletal muscles, and subcutaneous tissue. Occasionally the heart, lung, and peritoneum may also be involved (Obrador, 1948 ; Arseni and Samitca, 1957). Involvement of the brain and meninges is far more common than of the spinal cord. The rarity of involvement of the latter is stressed by the fact that Dixon and Lipscomb (1961) found that only one out of 450 cases of cysticercosis showed progressive tetraparesis as a result of spinal-cord involvement. Thus paraplegia as a presenting feature of cysticercosis is extremely rare. We report here the case of a patient in whom a cysticercus cyst removed at operation from the spinal cord was responsible for paraplegia.

\section{CAse Report}

A Sikh aged 40 was admitted to the medical wards with a complaint of weakness of both lower limbs and loss of sensation over the lower half of his body for the previous three months. The onset was gradual, but rapid progress of the condition caused him to be bedridden within 10 days. There was no history of fever, root pains, or sphincter disturbance. Past and family histories were noncontributory. He was a strict vegetarian and had never eaten at any hotel or restaurant.

Physical examination showed him to be moderately built and poorly nourished. His temperature was $98.6^{\circ} \mathrm{F}$. $\left(37^{\circ} \mathrm{C}\right.$.), pulse 82, and blood-pressure $120 / 70 \mathrm{~mm}$. Hg. Cardiovascular, respiratory, and abdominal examination showed no abnormality. Examination of the nervous system revealed that the higher functions, speech, and cranial nerves were normal. Fundus examination did not disclose anything of note. Motor, sensory, and cerebellar functions were normal in the upper extremities. On investigation the lower 